\title{
Students' Perception on The Use of Google Classroom in English Online Learning at A Rural Junior High School
}

\author{
Periani, K ${ }^{1 *}$, Suputra, P. E. D D $^{\mathbf{D}}$ \\ 1,2 English Language Education, Ganesha University of Education, Singaraja, Indonesia
}

\section{A R T I C L E I N F O}

Article history:

Received September 20, 202

Revised September 22, 2021

Accepted November 17, 2021

Available online December 25, 2021

Kata Kunci:

Persepsi, Google Classroom,

Persepsi Siswa

Keywords:

Perception, Google Classroom,

Student Perception

DOI:

http://dx.doi.org/10.23887/jpbi.v9i3 .43763

\begin{abstract}
A B S T R A K
Pandemi COVID-19 menyebabkan proses pembelajaran yang awalnya dilakukan di kelas berubah menjadi pembelajaran online. Hal tersebut menyebabkan guru membutuhkan media untuk mendukung pembelajaran online. Permasalahan saat ini adalah terbatasnya jaringan mahasiswa karena kondisi geografis. Siswa juga bingung mengoperasikan Google Classroom dalam kondisi tertentu karena kurangnya pengetahuan tentang penggunaan platform pedagogis. Penelitian ini bertujuan untuk menganalisis persepsi siswa tentang penggunaan google classroom dalam pembelajaran bahasa Inggris online di sekolah menengah pedesaan. Penelitian ini dirancang dengan menggunakan studi kualitatif. Pengumpulan data dilakukan melalui 2 instrumen yaitu angket dan wawancara. Kemudian, teori Miles dan Huberman digunakan dalam menganalisis data dimana analisis data terdiri dari empat bagian: pengumpulan data, reduksi data, penyajian data, dan penarikan kesimpulan/verifikasi. Hasil studinya adalah. Pertama, persepsi siswa terhadap Google Classroom sebagai media pembelajaran online dikategorikan positif. Kedua, kendala yang dihadapi siswa selama penerapan Google Classroom dalam pembelajaran online adalah terbatasnya interaksi antar siswa karena siswa fokus berinteraksi dengan guru, dan siswa menganggap Google Classroom tidak efektif karena tidak dapat beradaptasi dengan aplikasi terlihat dari respon siswa ketika beberapa diantaranya kurang paham tentang fitur-fitur di Google Classroom. Ketiga, siswa memiliki keluhan saat mengakses Google Classroom dimana siswa tidak dapat mengikuti kelas karena tidak memiliki data seluler yang berarti tidak dapat mengakses Google Classroom dan tidak dapat belajar mata kuliah online. Keempat, siswa terlambat mengumpulkan tugas karena menunggu data seluler dan internet. Dapat disimpulkan bahwa penggunaan google classroom dalam pembelajaran mengalami beberapa kendala, sehingga perlu diperhatikan.
\end{abstract}

\section{A B S T RA C T}

The COVID-19 pandemic has caused the learning process initially done in class to turn into online learning. It causes teachers to need media to support online learning. The current problem is the limited student network due to geographical conditions. The students were also confused about operating Google Classroom under certain conditions due to a lack of knowledge about using the pedagogical platform. This study aimed to analyze students' perceptions of the use of google classroom in online English learning in rural high schools. This research was designed using a qualitative study. Data was collected through 2 instruments, namely questionnaires and interviews. Then, Miles and Huberman's theory is used in analyzing data where data analysis consists of four parts: data collection, data reduction, data presentation, and conclusion drawing/verification. The study results are. First, students' perceptions of Google Classroom as an online learning medium are categorized as positive. Second, the obstacles faced by students during the implementation of Google Classroom in online learning are limited interaction between students because students focus on interacting with teachers, and students consider Google Classroom ineffective because it cannot adapt to applications as seen from student responses when some of them do not understand about features in Google Classroom. Third, students have complaints when accessing Google Classroom where students cannot join classes because they do not have cellular data, which means they cannot access Google Classroom and cannot study online courses. Fourth, students are late submitting assignments because they are waiting for cellular and internet data. It can be concluded that the use of google classroom in learning experiences several obstacles, so it needs to be considered.

This is an open-access article under the CC BY-SA license. Copyright @ 2021 by Author. Published by Universitas Pendidikan Ganesha.

\section{INTRODUCTION}

COVID-19, which we know as the Coronavirus pandemic, has changed people's lives in various sectors, including education. This COVID-19 was claimed as a world crisis on January 30, 2020, and a global pandemic on March 11, 2020, by the World Health Organization (W. Ali, 2020; Handayani et al., 2020; Prawiyogi et al., 2020; Yulia, 2020). For now, COVID-19 is still affecting several countries, especially Indonesia, and the number of confirmed deaths has reached nearly 4 million (Dhawan, 2020; Shah et al., 2020; Shodiq \& Zainiyati, 2020). By knowing the dangers of the Coronavirus, Indonesia has considered and implemented a social distancing strategy 
to separate social interactions and lockdown to prevent the spread of the disease (Karasmanaki \& Tsantopoulos, 2021; Sit \& Assingkily, 2020). Various measures have been taken to prevent the spread of this virus in Indonesia. Especially in the sector of education face-to-face learning was changed to online learning (E. Y. H. Lau \& Lee, 2021; Mustakim, 2020; Ran \& Jinglu, 2020). Based on the preliminary observation that has been conducted it was found that the students were using Google Classroom in online learning. It means that the teacher was implementing Google Classroom as a medium to support online learning. In the observed school, the implication of this approach was having a problem on students' limited network because of the geographical condition. The students also got confused about the way to operate Google Classroom in specific conditions caused by the lack of knowledge on the use of the pedagogical platform. This study is further interested to investigate students' perception toward the use of Google Classroom in English online learning. The urgencies of conducting this research are to find out the perception of students who seem to rarely use Google Classroom in online learning.

Currently, technology is increasingly advanced because it has a role in learning. Technology seems to make work easier and less time-consuming (Astuti et al., 2021; Lynch et al., 2021; Tuma, 2021). The learning process has been carried out online which was facilitated by technology as a previous media because of e-learning. In the online learning process, school devices use media as an effective interaction tool that can be accessed by students and teachers (Ellianawati et al., 2021; E. Y. H. Lau \& Lee, 2021; Mustakim, 2020). In line with technological developments, many platforms provide educational services that underlie online learning, such as WhatsApp, Zoom, Quipper School, Ruang Guru, Webex, Google Meet, and the like (Arizona et al., 2020; Putra, 2021; Setyawan et al., 2020; Suhery et al., 2020). One of the most widely used learning platforms is Google Classroom (Al-Maroof \& Al-Emran, 2018; Santosa et al., 2020). Google Classroom is one of the learning applications designed and developed by Google for academic purposes that is easy to use (Maharani \& Kartini, 2019; Putra, 2021). Google Classroom is a blended learning platform with attractive and simple features for schools (Amrina \& Sundari, 2021; Khalil, 2018; Mahitsa \& Mahardini, 2020). It is easy for students and teachers to do online learning with this platform. Google Classroom is a tool that is used as media for student and teacher collaboration. So that teachers can create and distribute assignments to students in online classes (Albashtawi \& Al Bataineh, 2020; Guswara, 2020; Permata \& Bhakti, 2020). Google Classroom can be a means that can involve students to be active in the online learning process. Teachers can create active, student-centered, and collaborative learning through this platform. In addition, teachers and students can carry out learning activities through online classes anytime and anywhere (M. K. Ali \& Maksum, 2020; Kurniawati et al., 2019; Soni et al., 2018).

In this case, it can lead to student perceptions of the learning process, it is expected to be able to develop and control themselves positively and be able to interact with the environment. In addition, in the implementation of learning students are required to be active not only as facilitators but also as spectators for themselves (Haka et al., 2020; Octaberlina \& Muslimin, 2020; Suhery et al., 2020). The word audience refers to the way people give their views about something. This term indicates the way people perceive something which is commonly called perception. Perception is described as a manner of recognizing and perceiving understanding facts (Dumitrescu et al., 2014; Edwards, 2018; Xu \& Wu, 2021). Perception is also defined as the ability to see, understand, then interpret a stimulus so that it becomes something meaningful and produces interpretation (Lau \& Li, 2019; Omotayo \& Haliru, 2020; Sorensen, 2013). Students' perceptions reflect their attitudes or behavior obtained from observations during the online learning process. The results of these observations will lead to a perception where the perception can be positive or negative depending on the observations of each individual. When online learning takes place, some students think online learning is not fun and very boring because they only listen and see movements through videos or direct movements from the teacher. This assumption is different from what is expected by teachers who try to make learning as interesting as possible so that students feel happy, comfortable and don't feel burdened to take part in online learning. The findings of previous studies also state that online learning can be assisted by using the google classroom application (Al-Maroof \& Al-Emran, 2018; Santosa et al., 2020; Sukmawati \& Nensia, 2019). Other research findings also state that online learning using google classroom can help students understand learning material (Maharani \& Kartini, 2019; Mahitsa \& Mahardini, 2020; Putra, 2021). It can be said that online learning using the Google Classroom application can be used during the COVID19 pandemic. There is no study on students' perceptions of the use of Google Classroom in online English learning. This study aims to analyze students' perceptions of the use of google classroom in online English learning in rural high schools. It is hoped that the use of Google Classroom can increase students' enthusiasm and understanding in learning.

\section{METHOD}

This research was designed in the form of qualitative research that uses a case study research design. Qualitative research is research that describes phenomena. The type of qualitative research used in this research was a case study research design. A case study is a research that investigates phenomena in real life. The phenomena described in this study Students Perception on The Use of Google Classroom in English Online 
Learning at 8th grade of SMP Ayodhya Pura, Selat. The study was conducted on 8th-grade students of SMP Ayodhya Pura, Selat. In this class, only 2 classes that used Google Classroom are at 8A and 8B, and the other class at 8 th grade uses WA application. Thus, only $8 \mathrm{~A}$ and $8 \mathrm{~B}$ have asked for data regarding perceptions on the use of Google Classroom. In this study, the researcher used questionnaires, interviews, and documentation to collect data. Three techniques were used to collect the data of this research namely, questionnaire, interview, and documentation. Furthermore, the interview technique was already held to get the deep analysis from the obtained data in the preview observation. Qualitative data analysis theory was used for data analysis there were four steps namely; Data collection, Data reduction, Data display, and Verification or Conclusion Drawing (Miles et al., 2014). In data collection, the data were collected from the two instruments, which are the questionnaire and interview guide. The data from the questionnaire was used to find students' perceptions on the used Google Classroom in English online learning. Furthermore, the data from the interview was conducted based on the data analysis found through a questionnaire. The data reduction, the data were reduced to find the data based on the researcher's need. Data display. In this study, the data were displayed in writing of the data. There was no number and statistical analysis. The data was described in detail. In Verification or Conclusion in this study, the data were verified by relating the finding with the literature review. After that, the data were concluded to answer the statement of the problem.

\section{RESULT AND DISCUSSION}

\section{Result}

Based on the data from the questionnaire, this study found several responses from the students by using a questionnaire consisting of 21 questions. These were the students' responses to each question. The result of the questionnaire can be seen in Table 1. Based on the result of the questionnaire, it can be seen that most of the students in SMP Ayodhya Pura have a positive perception of Google Classroom.

Table 1. Result of the questionnaire

\begin{tabular}{|c|c|c|}
\hline No & Statements & Response \\
\hline 1 & I know and understand what E-Learning is. & $43.1 \%$ of $100 \%$ agree \\
\hline 2 & I know and understand what Google classrooms are. & $53.4 \%$ of $100 \%$ agree \\
\hline 3 & $\begin{array}{l}\text { The Google Classroom application is very flexible for students } \\
\text { in utilizing online learning. }\end{array}$ & $44.8 \%$ of $100 \%$ agree \\
\hline 4 & $\begin{array}{l}\text { I like how learning is held using Google classroom at SMP } \\
\text { Ayodhya Pura, Selat, }\end{array}$ & $41.4 \%$ of $100 \%$ agree \\
\hline 5 & $\begin{array}{l}\text { There is no difficulty in operating Google Classroom on an } \\
\text { online learning system. }\end{array}$ & $39.7 \%$ of $100 \%$ agree \\
\hline 6 & $\begin{array}{l}\text { Google Classroom is the right learning medium to be } \\
\text { implemented at SMP Ayodhya Pura, Selat, Buleleng }\end{array}$ & $56.9 \%$ of $100 \%$ agree \\
\hline 7 & The facilities at my house support access to E-Learning & $37.9 \%$ of $100 \%$ neutral \\
\hline 8 & $\begin{array}{l}\text { The google classroom application gives me benefits in the } \\
\text { learning process }\end{array}$ & $55.2 \%$ of $100 \%$ agree \\
\hline 9 & $\begin{array}{l}\text { With the application of google classroom, I can study and do } \\
\text { assignments wherever I am when I am connected to the } \\
\text { internet. }\end{array}$ & $44.8 \%$ of $100 \%$ agree \\
\hline 10 & $\begin{array}{l}\text { I am happy to be able to ask questions and answers from class } \\
\text { teachers and classmates }\end{array}$ & $50 \%$ of $100 \%$ agree \\
\hline 11 & $\begin{array}{l}\text { The appearance of google classroom is very clear and easy to } \\
\text { understand }\end{array}$ & $43.1 \%$ of $100 \%$ agree \\
\hline 12 & $\begin{array}{l}\text { With google classroom, it is easy to get material } \\
\text { announcements and efficient assignment submissions }\end{array}$ & $44.8 \%$ of $100 \%$ agree \\
\hline 13 & $\begin{array}{l}\text { By using google classroom, I'm more active in the learning } \\
\text { process }\end{array}$ & $41.4 \%$ of $100 \%$ agree \\
\hline 14 & Google classroom is easy to access & $44.8 \%$ of $100 \%$ agree \\
\hline 15 & Some teachers never use E-Learning & $37.9 \%$ of $100 \%$ neutral \\
\hline 16 & E-Learning learning is more fun than face-to-face learning. & $43.1 \%$ of $100 \%$ neutral \\
\hline 17 & I open E-Learning only if there are assignments. & $41.4 \%$ of $100 \%$ agree \\
\hline 18 & I find it difficult to study with google classroom. & $39.7 \%$ of $100 \%$ neutral \\
\hline 19 & $\begin{array}{l}\text { In my opinion, collecting assignments in the form of files is } \\
\text { difficult for students }\end{array}$ & $41.4 \%$ of $100 \%$ neutral \\
\hline
\end{tabular}




\begin{tabular}{lll}
\hline No & Statements & Response \\
\hline 20 & $\begin{array}{l}\text { I don't feel confident if my assignment file is sent to the } \\
\text { Google Classroom group. }\end{array}$ & $34.5 \%$ of 100\% neutral \\
21 & $\begin{array}{l}\text { I am not interested in the online learning system via google } \\
\text { classroom. }\end{array}$ & $37.9 \%$ of $100 \%$ neutral \\
\hline
\end{tabular}

Table 2. Transcript of Interview Guide

\begin{tabular}{|c|c|}
\hline Question & Response \\
\hline $\begin{array}{l}\text { Is online learning with } \\
\text { Google Classroom able to } \\
\text { build social interaction } \\
\text { between students and other } \\
\text { students? Why? }\end{array}$ & $\begin{array}{l}\text { - I don't think so, because we learn online, we only interact with the teacher } \\
\text { (S-1) } \\
\text { - I don't think so, I never interacted with my teammates in Google Classroom } \\
\text { (S-2) } \\
\text { - No, because it can only build interaction between teacher and student (S-3) } \\
\text { - No, because in my opinion google classroom is only able to build social } \\
\text { interaction between students and teachers (S-4) } \\
\text { - No because it is only able to build social interaction for teachers and } \\
\text { students (S-5) } \\
\text { - No, because in my opinion Google Classroom is only able to build social } \\
\text { interaction between students and teachers (S - 9) } \\
\text { - In my opinion, it is not easy to understand online learning using google } \\
\text { classroom (S-10) } \\
\text { - Less effective, because I use the google classroom application, I don't } \\
\text { understand the subject matter (S-11) } \\
\text { - For me, learning through google classroom is not good, because I don't } \\
\text { understand the lessons in google classroom (S-12) } \\
\text { - Not yet (S-15) }\end{array}$ \\
\hline $\begin{array}{l}\text { How do you understand } \\
\text { online learning with Google } \\
\text { Classroom? }\end{array}$ & $\begin{array}{l}\text { - I don't agree, because Google Classroom need internet fees (S-1) } \\
\text { - My experience during online learning was that I was late in sending } \\
\text { assignments due to quota constraints (S-2) } \\
\text { - My solution is if you learn to use Google Classroom, the government can } \\
\text { give free cellular data (S-6) }\end{array}$ \\
\hline $\begin{array}{l}\text { How do you respond when } \\
\text { online learning with Google } \\
\text { Classroom is applied in all } \\
\text { subjects rather than in-class } \\
\text { or face-to-face learning? }\end{array}$ & $\begin{array}{l}\text { - My experience has been late in sending assignments (S-13) } \\
\text { - My experience has never been to take part in the learning process because } \\
\text { there is no cellular data (S-14) } \\
\text { - Hopefully, it can be easily accessed (S-15) }\end{array}$ \\
\hline
\end{tabular}

Furthermore, based on the result of the interview session, there are some obstacles faced by the students. First, the interaction between students and students is limited because the students focus on the interaction with the teacher. It can be seen that the interaction is limited in online sessions because the students only focus on instruction from the teacher and the students need to pay attention to it because the online learning somehow is unstable which means if they miss part of the discussion, the students will be difficult to re-track the discussion. Second, the students are difficult to adapt to Google Classroom which resulted from their comfort in learning. It can be seen the students think Google Classroom is not effective because they cannot adapt to the application which can be seen with the response of the students when some of them cannot understand the feature in Google Classroom. Third, the students have a problem accessing the application which resulted in their learning process. It can be seen the students have complaints when accessing the Google Classroom in which the students cannot join the class because they do not have cellular data which means they cannot access Google Classroom and they cannot learn the online course. Next, the students submitted the task late because they are waiting for the cellular data and good internet to make the assignment submitted successfully.

\section{Discussion}

Based on the result of the questionnaire, it can be seen that most of the students in SMP Ayodhya Pura have a positive perception toward Google Classroom which can be seen from the mean which is 3.6. This is in line with the research, also exposed Students' Perception of Using Google Classroom for Teaching English by focusing on the view of using the application at the university level in Bangladesh in which $82 \%$ of learners said that google classroom easy to be used in anywhere and anytime (Islam, 2015). $56 \%$ said that the application can help to correct their mistakes. $85 \%$ said that video and quiz are interesting. Thus, the finding shows that students have a positive 
view toward the use of Google Classroom for speaking, listening, reading, and writing skills. By seeing the result of the questionnaire, it can be seen that although the students have the problem during using Google Classroom for learning, their perception is still positive which is in line with the research showed that Google Classroom is easy and helpful for both students and teachers' perspective although, many challenges were exposed to increase the use of application for higher education (Ali \& Maksum, 2020; Kumar et al., 2020; Permata \& Bhakti, 2020).

Based on the result of the interview guide, there are 3 main obstacles faced by the students in learning by using Google Classroom. First, the interaction between students and students is limited because the students focus on the interaction with the teacher. Because of that, online learning somehow is unstable which means if they miss part of the discussion, the students will be difficult to re-track the discussion (Albashtawi \& Al Bataineh, 2020; Khalil, 2018; Mahitsa \& Mahardini, 2020; Permata \& Bhakti, 2020). Online learning is a commitment and a resource that must be done right which means that online learning materials must be designed properly, with learners and learning in focus, and adequate support must be provided (Azhari \& Fajri, 2021; Lau \& Lee, 2021; Mansur et al., 2021; Mustakim, 2020). Based on the statement from Spector, it can be seen that compared to the situation in SMP Ayodhya Pura, online learning is still not done properly due to students' limited access to their learning which resulted in another problem for example late in submitting the assignment to the teacher.

Communication is important in connecting teachers and students during online learning to make sure the learning goes well however in SMP Ayodhya Pura, online learning is unstable. The unstable online learning happened because of the limited facilities for example internet connection in which must be existed in online learning because audio, video, computer, and network technologies are often combined to create diverse instructional delivery systems and the basic method of bringing distance learning instructors together with distance students is networking (Arizona et al., 2020; Hutauruk \& Sidabutar, 2020; Napsawati, 2020). Second, the students think Google Classroom is not effective because they cannot adapt to the application which can be seen with the response of the students when some of them cannot understand the feature in Google Classroom. The disadvantages of Google Classroom such as lack of human resources who understand the internet. Based on the statement of the theory, some of the students at SMP Ayodhya Pura cannot understand how to use Google Classroom, they need more understanding and practice in school how to use or access Google Classroom. Third, the students have complaints when accessing the Google Classroom in which the students cannot join the class because they do not have cellular data which means they cannot access Google Classroom and they cannot learn the online course. Next, the students submitted the task late because they are waiting for the cellular data and good internet to make the assignment submitted successfully. This is in line with the study show the students' side about seeing the barriers and discovered three barriers during online learning including unfamiliarity with the use of digital learning, limited internet connection, and physical condition (Heng \& Sol, 2020; Hwang et al., 2020; Mishra et al., 2020; Vlachopoulos, 2020). This is also in line with the study in which the study aims to explore the effectiveness of Google Classroom in the learning process.

\section{CONCLUSION}

Based on the data findings there were students' perceptions on the use of Google Classroom as online learning media is categorized as positive. The obstacles faced by students during the application of Google Classroom in online learning are first, the interaction between students and students is limited because the students focus on the interaction with the teacher. Second, The students think Google Classroom is not effective because they cannot adapt to the application which can be seen with the response of the students when some of them cannot understand the feature in Google Classroom. Third, the students have complaints when accessing the Google Classroom in which the students cannot join the class because they do not have cellular data which means they cannot access Google Classroom and they cannot learn the online course. Fourth, the students submitted the task late because they are waiting for the cellular data and good internet to make the assignment submitted successfully.

\section{REFERENCES}

Al-Maroof, R. A. S., \& Al-Emran, M. (2018). Students Acceptance of Google Classroom: An Exploratory Study using PLS-SEM Approach. International Journal of Emerging Technologies in Learning (IJET), 13(06), 112-123. https://doi.org/10.3991/ijet.v13i06.8275.

Albashtawi, A. H., \& Al Bataineh, K. B. (2020). The effectiveness of google classroom among EFL students in Jordan: An innovative teaching and learning online platform. International Journal of Emerging Technologies in Learning, 15(11), 78-88. https://doi.org/10.3991/IJET.V15I11.12865.

Ali, M. K., \& Maksum, H. (2020). Utilization of E-Learning-Based ICT Learning Using the Google Classroom Application During the COVID-19 Pandemic. Journal of Education Research and Evaluation, 4(4), 373. https://doi.org/10.23887/jere.v4i4.29181. 
Ali, W. (2020). Online and Remote Learning in Higher Education Institutes: A Necessity in light of COVID-19 Pandemic. Higher Education Studies, 10(3), 16-25. https://doi.org/10.5539/hes.v10n3p16.

Amrina, R., \& Sundari, H. (2021). Learning from Home Environment: Academic Writing Course for EFL Undergraduates through Google Classroom Application. Studies in English Language and Education, 8(2), 710-725. https://doi.org/10.24815/siele.v8i2.18374.

Arizona, K., Abidin, Z., \& Rumansyah, R. (2020). Pembelajaran Online Berbasis Proyek Salah Satu Solusi Kegiatan Belajar Mengajar Di Tengah Pandemi Covid-19. Jurnal Ilmiah Profesi Pendidikan, 5(1). https://doi.org/10.29303/jipp.v5i1.111.

Astuti, M., Arifin, Z., Mutohhari, F., \& Nurtanto, M. (2021). Competency of Digital Technology: The Maturity Levels of Teachers and Students in Vocational Education in Indonesia. Journal of Education Technology, 5(2), 254-262. https://doi.org/10.23887/jet.v5i3.35108.

Azhari, B., \& Fajri, I. (2021). Distance learning during the COVID-19 pandemic: School closure in Indonesia. International Journal of Mathematical Education in Science and Technology. https://doi.org/10.1080/0020739X.2021.1875072.

Dhawan, S. (2020). Online Learning: A Panacea in the Time of COVID-19 Crisis. Journal of Educational Technology Systems, 49(1), 5-22. https://doi.org/10.1177/0047239520934018.

Dumitrescu, C., Olteanu, R. L., Gorghiu, L. M., \& Gorghiu, G. (2014). Learning Chemistry in the Frame of Integrated Science Modules - Romanian Student's Perception. Procedia - Social and Behavioral Sciences, 116(September 2015), 2516-2520. https://doi.org/10.1016/j.sbspro.2014.01.603.

Edwards, O. W. (2018). School perceptions of children raised by grandparents. Journal of Applied School Psychology, 34(1), 86-100. https://doi.org/10.1080/15377903.2017.1403401.

Ellianawati, E., Subali, B., Khotimah, S. N., Cholila, M., \& Darmahastuti, H. (2021). Face to Face Mode vs. Online Mode: A Discrepancy in Analogy-Based Learning During COVID-19 Pandemic. Jurnal Pendidikan IPA Indonesia, 10(3), 368-377. https://doi.org/10.15294/jpii.v10i3.30037.

Guswara, A. M. (2020). The Contribution of Google Classroom Application and Motivation to The Learning Outcomes of Web Programming. Educational Technology, 4(4), 1-9. https://doi.org/10.23887/jet.v4i4.29896.

Haka, N. B., Anggita, L., Anggoro, B. S., \& Hamid, A. (2020). Pengaruh Blended Learning Berbantukan Google Classroom Terhadap Keterampilan Berpikir Kreatif Dan Kemandirian Belajar Peserta Didik. Edu Sains Jurnal Pendidikan Sains \& Matematika. https://doi.org/10.23971/eds.v8i1.1806.

Handayani, Hadi, Isbaniah, Burhan, \& Agustin. (2020). Corona Virus Disease 2019. Jurnal Respirologi Indonesia", 40(2). https://doi.org/10.36497/jri.v40i2.101.

Heng, K., \& Sol, K. (2020). Online learning during COVID-19: Key challenges and suggestions to enhance effectiveness. Cambodian Education Forum (CEF). https://doi.org/10.1371/journal.pone.0248758.

Hutauruk, A., \& Sidabutar, R. (2020). Kendala pembelajaran daring selama masa pandemi di kalangan mahasiswa pendidikan matematika: Kajian kualiatatif deskriptif. Journal of Mathematics Education and Applied, 02(01), 45-51. https://doi.org/10.36655/sepren.v2i1.364.

Hwang, G. J., Wang, S. Y., \& Lai, C. L. (2020). Effects of a social regulation-based online learning framework on students' learning achievements and behaviors in mathematics. Computers and Education, 160, 104031. https://doi.org/10.1016/j.compedu.2020.104031.

Islam, M. S. (2015). Bangladesh University Students' Perception on Using Google Classroom for Teaching English. International Journal of Psycho-Educational Sciences, 8(2).

Karasmanaki, E., \& Tsantopoulos, G. (2021). Impacts of social distancing during COVID-19 pandemic on the daily life of forestry students. Children and Youth Services Review, 120(December 2020), 105781. https://doi.org/10.1016/j.childyouth.2020.105781.

Khalil, Z. M. (2018). EFL Students' Perceptions towards Using Google Docs and Google Classroom as Online Collaborative Tools in Learning Grammar. Applied Linguistics Research Journal, 2(2), 33-48. https://doi.org/10.14744/alrj.2018.47955.

Kumar, J. A., Bervell, B., \& Osman, S. (2020). Google Classroom : insights from Malaysian higher education students ' and instructors ', experiences. Education and Information Technologies, 25. https://doi.org/10.1007/s10639-020-10163-X.

Kurniawati, M., Santanapurba, H., \& Kusumawati, E. (2019). Penerapan Blended Learning Menggunakan Model Flipped Classroom Berbantuan Google Classroom Dalam Pembelajaran Matematika Smp. EDU-MAT: Jurnal Pendidikan Matematika, 7(1), 8-19. https://doi.org/10.20527/edumat.v7i1.6827.

Lau, E. Y. H., \& Lee, K. (2021). Parents' Views on Young Children's Distance Learning and Screen Time During COVID-19 Class Suspension in Hong Kong. Early Education and Development, 32(6), 863-880. https://doi.org/10.1080/10409289.2020.1843925.

Lau, M. M., \& Li, H. (2019). Whole-day or half-day kindergarten? Chinese parents' perceptions, needs, and decisions in a privatized marketplace. Children and Youth Services Review, 105. 
https://doi.org/10.1016/j.childyouth.2019.104427.

Lynch, M., Sage, T., Hitchcock, L. I., \& Sage, M. (2021). A heutagogical approach for the assessment of Internet Communication Technology (ICT) assignments in higher education. International Journal of Educational Technology in Higher Education, 18(1). https://doi.org/10.1186/s41239-021-00290-x.

Maharani, N., \& Kartini, K. S. (2019). Penggunaan google classroom sebagai pengembangan kelas virtual dalam keterampilan pemecahan masalah topik kinematika pada mahasiswa jurusan sistem komputer. PENDIPA Journal of Science Education, 3(3), 167-173. https://doi.org/10.33369/pendipa.3.3.167-173.

Mahitsa, M., \& Mahardini, A. (2020). Analisis Situasi Penggunaan Google Classroom pada Pembelajaran Daring Fisika. Jurnal Pendidikan FIsika, VIII(2), 215-224. https://doi.org/10.24127/jpf.v8i2.3102 ANALISIS.

Mansur, H., Jumadi, Mastur, Utama, A. H., \& Prastitasari, H. (2021). The Problem of Distance Learning During the Covid-19 Pandemic. Ilkogretim Online - Elementary Education Online, 20(4), 168-175. https://doi.org/10.17051/ilkonline.2021.04.19.

Miles, M. B., Huberman, A. M., \& Saldana, J. (2014). Qualitative Data Analysis.

Mishra, L., Gupta, T., \& Shree, A. (2020). Online teaching-learning in higher education during lockdown period of COVID-19 pandemic. International Journal of Educational Research Open, 1, 100012. https://doi.org/10.1016/j.ijedro.2020.100012.

Mustakim, M. (2020). Efektivitas Pembelajaran Daring Menggunakan Media Online Selama Pandemi Covid-19 Pada Mata Pelajaran Matematika. Al Asma: Journal of Islamic Education, 2(1), 1-12. https://doi.org/10.24252/asma.v2i1.13646.

Napsawati, N. (2020). Analisis Situasi Pembelajaran IPA Fisika Dengan Metode Daring Di Tengah Wabah Covid19. Karst: Jurnal Pendidikan Fisika Dan Penerapannya, 3(1), 96-102. https://doi.org/10.46918/karst.v3i1.546.

Octaberlina, L. R., \& Muslimin, A. I. (2020). EFL Students Perspective towards Online Learning Barriers and Alternatives Using Moodle / Google Classroom during COVID-19 Pandemic. International Journal of Higher Education, 9(6), 1-9. https://doi.org/10.5430/ijhe.v9n6p1.

Omotayo, F. O., \& Haliru, A. (2020). Perception of Task-Technologyfit of Digital Library among Undergraduates in Selected Universities in Nigeria. The Journal of Academic Librarianship, 46(1), 102097. https://doi.org/10.1016/j.acalib.2019.102097.

Permata, A., \& Bhakti, Y. B. (2020). Keefektifan Virtual Class dengan Google Classroom dalam Pembelajaran Fisika Dimasa Pandemi Covid-19. JIPFRI (Jurnal Inovasi Pendidikan Fisika Dan Riset Ilmiah), 4(1), 27-33. https://doi.org/10.30599/jipfri.v4i1.669.

Prawiyogi, A. G., Purwanugraha, A., Fakhry, G., \& Firmansyah, M. (2020). Efektifitas Pembelajaran Jarak Jauh Terhadap Pembelajaran Peserta didik di SDIT Purwakarta. JPD: Jurnal Pendidikan Dasar, 11(1). https://doi.org/10.21009/10.21009/JPD.081.

Putra, R. W. P. (2021). Improving the Students' Motivation in Learning English through Google Meet during the Online Learning. English Learning Innovation, 2(1), 35-42. https://doi.org/10.22219/englie.v2i1.14605.

Ran, W., \& Jinglu, L. (2020). The Design and Development of Digital Books for E-learning. 2020 4th International Conference on Artificial Intelligence and Virtual Reality, 51-55. https://doi.org/10.1145/3439133.3439140.

Santosa, F. H., Negara, H. R. P., \& Samsul Bahri. (2020). Efektivitas Pembelajaran Google Classroom Terhadap Kemampuan Penalaran Matematis Siswa. Jurnal Pemikiran Dan Penelitian Pendidikan Matematika (JP3M), 3(1), 62-70. https://doi.org/10.36765/jp3m.v3i1.254.

Setyawan, A., Aznam, N., \& Citrawati, T. (2020). Effects of the Google Meet Assisted Method of Learning on Building Student Knowledge and Learning Outcomes. Universal Journal of Educational Research, 8(9), 3924-3936. https://doi.org/10.13189/ujer.2020.080917.

Shah, K., Arfan, M., Mahariq, I., Ahmadian, A., Salahshour, S., \& Ferrara, M. (2020). Fractal-Fractional Mathematical Model Addressing the Situation of Corona Virus in Pakistan. Results in Physics, 19, 103560. https://doi.org/10.1016/j.rinp.2020.103560.

Shodiq, I. J., \& Zainiyati, H. S. (2020). Pemanfaatan Media Pembelajaran E-Learning Menggunakan Whastsapp Sebagai Solusi Ditengah Penyebaran Covid-19 Di Mi Nurulhuda Jelu. Al-Insyiroh: Jurnal Studi Keislaman, 6(2), 144-159. https://doi.org/10.35309/alinsyiroh.v6i2.3946.

Sit, M., \& Assingkily, M. S. (2020). Persepsi Guru tentang Social Distancing pada Pendidikan AUD Era New Normal. Jurnal Obsesi: Jurnal Pendidikan Anak Usia Dini, 5(2), 1009-1023. https://doi.org/10.31004/obsesi.v5i2.756.

Soni, Hafid, Hayami, Fatma, Wenando, Amien, Fuad, Unik, \& Mukhtar. (2018). Optimalisasi Penggunaan Google Classroom, E-Learning \& Blended Learning sebagai Media Pembelajaran Bagi Guru dan Siswa di SMK Negeri 1 Bangkinang. Jurnal Pengabdian Untukmu Negeri, 21. https://doi.org/10.37859/jpumri.v2i1.361.

Sorensen, E. (2013). Implementation and student perceptions of e-assessment in a Chemical Engineering module. $\begin{array}{lllll}\text { European Journal of Engineering } & \text { Education, } & 38(2), & 185 .\end{array}$ 
https://doi.org/10.1080/03043797.2012.760533.

Suhery, S., Putra, T. J., \& Jasmalinda, J. (2020). Sosialisasi Penggunaan Aplikasi Zoom Meeting Dan Google Classroom Pada Guru Di Sdn 17 Mata Air Padang Selatan. Jurnal Inovasi Penelitian, 1(3), 129-132. https://doi.org/10.47492/jip.v1i3.90.

Sukmawati, S., \& Nensia, N. (2019). The Role of Google Classroom in ELT. International Journal for Educational and Vocational Studies, 1(2). https://doi.org/10.29103/ijevs.v1i2.1526.

Tuma, F. (2021). The use of educational technology for interactive teaching in lectures. Annals of Medicine and Surgery 62, 231-235. https://doi.org/10.1016/j.amsu.2021.01.051.

Vlachopoulos, D. (2020). COVID-19: Threat or Opportunity for Online Education? Higher Learning Research Communications, 10(1), 2. https://doi.org/10.18870/hlrc.v10i1.1179.

Xu, X., \& Wu, H. (2021). Audio-visual interactions enhance soundscape perception in China's protected areas. Urban Forestry \& Urban Greening, 61. https://doi.org/10.1016/j.ufug.2021.127090.

Yulia, H. (2020). Online Learning to Prevent the Spread of Pandemic Corona Virus in Indonesia. ETERNAL (English Teaching Journal), 11(1). https://doi.org/10.26877/eternal.v11i1.6068. 